\title{
AN IMMUNOFLUORESCENCE TEST FOR DIAGNOSIS OF OPHTHALMIC HERPES IN A MOUSE CORNEAL MODEL
}

\author{
Sílvia Regina Ferreira Gonçalves PEREIRA(1), Fernando Portela CÂMARA(2), Maria Angélica Arpon Marandino GUIMARÃES(3), Leonardo VIEIRA NETO(3),
} Daniel SEGENREICH(3), Antônio Carlos da Costa GUIMARÃES(3) \& Vera Lucia Antunes CHAGAS(4)

\begin{abstract}
SUMMARY
Herpes simplex virus type 1 (HSV-1) ophthalmic disease is the most common cause of corneal blindness in humans worldwide. Current culture techniques for HSV take several days and commercially available HSV laboratory based diagnostic techniques vary in sensitivity. Our study was conducted to evaluate the use of a quicker and simpler method to herpes ophthalmic diagnosis. Corneal smears were made by firm imprints of infected mouse eyes to glass slides, after smears were fixated with cold acetone, and an indirect immunofluorescence (IIF) method was performed using monoclonal antibodies in a murine model of ophthalmic herpes. Eye swabs from infected mice were inoculated in Vero cells for virus isolation. Cytology and histology of the eye were also performed, using hematoxylin-eosin routine. Mouse eyes were examined by slit-lamp biomicroscopy for evidence of herpetic disease at various times postinoculation. We made a comparative evaluation of sensitivity, specificity and speed of methods for laboratory detection of HSV. Our results indicate that this IIF method is quick, sensitive, specific and can be useful in the diagnosis of ophthalmic herpes as demonstrated in an animal model.
\end{abstract}

KEYWORDS: Herpes simplex virus type 1; Ophthalmic herpes; Murine model; Monoclonal antibodies; Indirect immunofluorescence.

\section{INTRODUCTION}

Herpes simplex virus type 1 (HSV-1) ophthalmic disease is a significant cause of blindness in humans world-wide ${ }^{8,9}$. It is known that HSV-1 produces a diversity of clinical syndromes in the eye. The most common consists of a keratitis frequently followed by

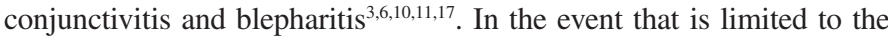
corneal epithelium, the pathogenesis appears to be due to viral cell destruction resulting in corneal ulceration ${ }^{3,6,10,11,17}$. However, sometimes, episodes of herpetic ophthalmic disease result in the involvement of the deeper corneal tissue leading to corneal scarring with consequent reduction in visual acuity. Additionally, delay in the treatment of HSV1 ophthalmic disease can lead to a more significant corneal scar, and topical steroid treatment in unsuspected active herpes ophthalmic can lead to corneal melting ${ }^{3,4,6,10,11,15}$.

Essentially the present information regarding the ophthalmic herpes comes from studies done in laboratory animals ${ }^{4,5,10,11,15}$. Therefore, we had previously optimized a murine model of HSV-1 ophthalmic disease, in which $\mathrm{BALB} / \mathrm{c}$ mouse corneas were inoculated without trauma and with HSV-1 strain obtained from a patient with severe herpetic disease, to mimic the infection in humans $\mathrm{s}^{4,5,10,11,15}$.

The diagnosis of ophthalmic herpes in humans is currently limited to virus isolation by cell cultures or serologic tests ${ }^{1,2,16}$. The suitability of efficient anti-herpes therapy has increased the demand for quick and sensitive diagnostic methods. In the present study, we have used our murine model to establish an alternative method for detection of HSV-1 by indirect immunofluorescence technique (IIF) starting from tissue imprints. The kinetic of viral infection at postinoculation (p.i.) intervals was investigated by IIF antigen detection and was compared to the virus isolation in Vero (African green monkey kidney) cells. The results obtained from both methodologies were combined to cytopathological and histopathological studies of the eye, as clinical signs of herpetic ophthalmic infection observed in infected mice.

\section{MATERIALS AND METHODS}

Virus and mice infection: A HSV-1 strain was isolated in Vero cells from a vesicle fluid of a patient with severe herpetic disease, and

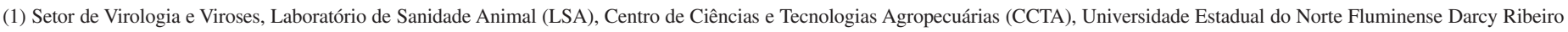
(UENF), Campos dos Goytacazes, RJ, Brasil.

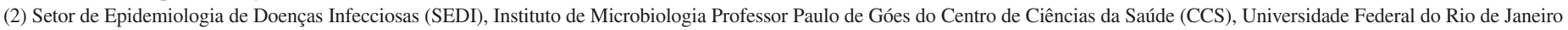
(UFRJ), Rio de Janeiro, RJ, Brasil.

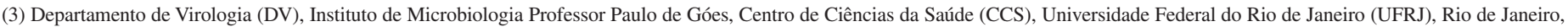
RJ, Brasil.

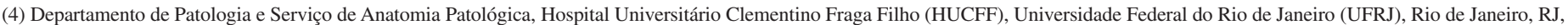
Brasil.

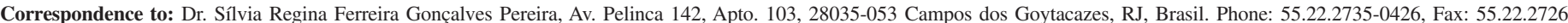
1549. E-mail: silviarfgp@uenf.br 


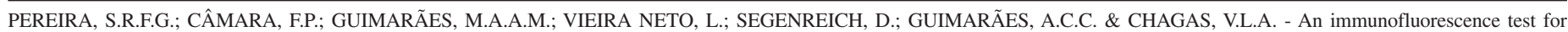
diagnosis of ophthalmic herpes in a mouse corneal model. Rev. Inst. Med. trop. S. Paulo, 49(2): 87-92, 2007.

was used in this study for mice infection. Viral inoculum was prepared as described previously in our studies ${ }^{10,11}$. Three-week-old male BALB/ c mice were maintained as a breeding colony in the Virology Department of the Federal University of Rio de Janeiro (RJ, Brazil), and were used in this study. All mice were anesthetized by inhalation of general anesthetic (ether; Merck, Darmstadt, Germany), their eyes were examined by a slit-lamp biomicroscope (SL 5; Kowa Co., Ltd., Nagoya, Japan) before virus infection, and any with abnormal eyes were discarded. Forty mice were bilaterally inoculated with the HSV1 strain propagated in Vero cells (viral inoculum) containing a predetermined number of infectious virus particles. A $10 \mu \mathrm{L}$ droplet of viral inoculum, containing $10^{6.5} \mathrm{CCID}_{50} / \mathrm{mL}$ infectious particles, was placed directly onto intact corneas (non-traumatic topical inoculation) and gently massaged in using the eyelids. Ten control mice were inoculated in the same way with a $10 \mu \mathrm{L}$ droplet of uninfected Vero cells prepared in the same manner as the viral inoculum (mock inoculum). All experimental procedures conformed to the National Institute of Health (NIH) guidelines and Association for Research in Vision and Ophthalmology (ARVO) resolution on the use and care of animals in research.

Clinical examination and monitoration of herpetic ophthalmic disease: Twenty virus-infected mice and five uninfected control mice were used in this clinical experiment. After these mice were anesthetized by inhalation of the general anesthetic, their eyes were examined for clinical signs of infection by slit-lamp monitoration on the inoculation day and then daily for 14 consecutive days. Progression of clinical signs of herpetic ophthalmic infection was appraised as described previously ${ }^{10,11,14}$.

Antigen detection by IIF from corneal imprints of mice: Indirect immunofluorescence (IIF) method was carried out with the same twenty virus-infected mice and five uninfected control mice. For detection of viral antigen the IIF method was performed as follows. In order to make corneal imprints, mouse eyes were gently but firmly imprinted directly onto glass slides, which were properly identified. Corneal imprints were then air-dried and fixed with chilled acetone (Merck). The primary antibody, a rabbit anti-HSV antibody (DAKO Corporation, Santa Barbara, CA) was poured to the slides containing corneal imprints, and incubated at $35^{\circ} \mathrm{C}$ for one hour in a humid chamber to allow the antigen-antibody reaction to take place. After incubation, the slides were gently washed three times in a phosphate-buffered saline (PBS), $\mathrm{pH}$ 7.3. Excess PBS was blotted from the slides, and the secondary antibody, a fluorescein isothiocyanate (FITC)-conjugated goat anti-rabbit monoclonal antibody (DAKO) was put in contact to the material and incubated for 30 minutes at $35{ }^{\circ} \mathrm{C}$. This conjugated anti-specie antibody reacts with primary antibody bound in the first reaction. At the end of incubation, the slides were washed as before, and counterstained with a solution of Evan's blue in PBS to stain in red uninfected cells and the background of infected cells. Conjugated serum slides were used as controls. The conjugated control slides were initially incubated in PBS instead of the rabbit anti-HSV and then with the conjugated goat anti-rabbit. The slides were coverslipped using a Tris-buffered glycerol, $\mathrm{pH} 9.0 \pm 0.5$, as a mounting medium. The coverslips were observed and photographed for the presence of specific fluorescent inclusion under the epifluorescence microscope (Carl Zeiss, West Germany), using 20x and 40x neofluar objectives.
Virus isolation in Vero cells from conjunctival swabs of mice: The same twenty virus-infected mice and five uninfected control mice were used for the virus isolation in cell culture. For cell virus isolation, mouse eye swabs (conjunctival) were taken daily, beginning on 24 hours p.i. and for up to eight days p.i. Cotton swabs were transferred to a transport medium for posterior inoculation in Vero cell monolayers cultivated in tubes $(13 \times 100 \mathrm{~mm})$. Two tubes per mouse eye were inoculated daily. After tubes inoculation, Vero cell monolayers were incubated at $37{ }^{\circ} \mathrm{C}$ in an atmosphere of $5 \% \mathrm{CO}_{2}$ for until 10 days to observe HSV cytopathic effect (CPE).

Cytological and histological examination of mouse eyes: Another twenty virus-infected mice and five uninfected control mice were euthanized, by overdose of the general anesthetic, at the $2^{\text {nd }}, 5^{\text {th }}, 10^{\text {th }}$ and $14^{\text {th }}$ days p.i., and these were exclusively used for cytological and histological studies of the mouse eye. Eye histology was performed in paraffin-embedded sections onto glass slides, while cytology was executed in conjunctival swabbing onto glass slides. After these mice were euthanized, their eyes were enucleated and immediately fixed in $10 \%$ neutral buffered formalin, and $5 \mu \mathrm{m}$ paraffin-embedded sections were prepared. The sections as well as swabs were stained with hematoxylin and eosin (H\&E), mounted with Permount, and coverslipped for microscopic examination in an optic microscopic (Leitz Dialux, Germany) and to also be photographed in a photomicroscope (Nikon, Japan).

\section{RESULTS}

Clinical signs of herpetic ophthalmic infection: We previously optimized a murine model of HSV-1 ophthalmic disease, which mimics the ophthalmic herpes in humans ${ }^{10,11}$. In the previous and present experiments, our murine model showed clinical signs of herpetic ophthalmic infection such as conjunctivitis, epithelial keratitis, blepharitis, stromal keratitis and neovascularization, at various times following HSV-1 inoculation (Table 1). As expected, uninfected control mice (non-traumatically inoculated with mock inoculum) showed no sign of disease during the follow-up.

Virus-specific fluorescence from corneal imprints: Employing the murine model of ophthalmic herpes, we made a comparative evaluation of methods for laboratory detection of HSV. Our study was concentrated on the antigen detection of HSV, in order to establish an alternative method to ophthalmic herpes diagnosis. After consideration of the reagents and technical expertise available to verify viral infection, we established the IFI starting from imprints of virus-infected tissue (HSV-1-corneal imprints) as a very suitable method for HSV-1 antigen detection. This IIF method showed cells producing HSV-1-specific antigen, which was identified by the cytoplasmic apple-green fluorescence (Fig. 1). We included a control slide for each batch of specimen slides. Control slide was first read to verify the performance of the fluorescent procedure and the microscope, and when control exhibited proper reactivity, the mouse specimen slides were then read and interpreted. Infected mice were considered positive when clinical specimen contained one or more cells displaying HSV-1-specific fluorescence. Mice were considered negative when specimen exhibited no specific fluorescence with incoherent staining of cell debris, dull green staining of entire cells, and cells displaying stain red due to Evans' blue (counterstain). Evans' blue stains uninfected cells and the 


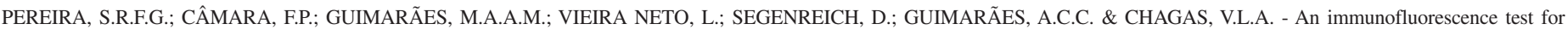
diagnosis of ophthalmic herpes in a mouse corneal model. Rev. Inst. Med. trop. S. Paulo, 49(2): 87-92, 2007.

Table 1

HSV-1 infected mice* showing clinical signs of herpetic ophthalmic infection

\begin{tabular}{|c|c|c|c|c|c|c|c|c|c|c|c|c|c|c|}
\hline \multirow[b]{2}{*}{ Clinical signs } & \multicolumn{13}{|c|}{ Time postinoculation (days) } & \multirow[b]{2}{*}{14} \\
\hline & 1 & 2 & 3 & 4 & 5 & 6 & 7 & 8 & 9 & 10 & 11 & 12 & 13 & \\
\hline Conjunctivitis & $0 / 20$ & $\begin{array}{l}8 / 20^{\mathrm{a}} \\
(40)^{\mathrm{b}}\end{array}$ & $\begin{array}{c}14 / 20 \\
(70)\end{array}$ & $\begin{array}{c}16 / 20 \\
(80)\end{array}$ & $\begin{array}{c}18 / 20 \\
(90)\end{array}$ & $\begin{array}{l}20 / 20 \\
(100)\end{array}$ & $\begin{array}{c}16 / 20 \\
(80)\end{array}$ & $\begin{array}{c}16 / 20 \\
(80)\end{array}$ & $\begin{array}{c}16 / 20 \\
(80)\end{array}$ & $\begin{array}{c}14 / 20 \\
(70)\end{array}$ & $\begin{array}{c}12 / 20 \\
(60)\end{array}$ & $\begin{array}{l}2 / 20 \\
(10)\end{array}$ & $\begin{array}{c}1 / 20 \\
(5)\end{array}$ & $0 / 20$ \\
\hline Epithelial keratitis & $0 / 20$ & $0 / 20$ & $\begin{array}{l}4 / 20 \\
(20)\end{array}$ & $\begin{array}{c}14 / 20 \\
(70)\end{array}$ & $\begin{array}{c}15 / 20 \\
(75)\end{array}$ & $\begin{array}{c}16 / 20 \\
(80)\end{array}$ & $\begin{array}{c}16 / 20 \\
(80)\end{array}$ & $\begin{array}{l}20 / 20 \\
(100)\end{array}$ & $\begin{array}{c}16 / 20 \\
(80)\end{array}$ & $\begin{array}{c}15 / 20 \\
(75)\end{array}$ & $\begin{array}{c}14 / 20 \\
(70)\end{array}$ & $\begin{array}{l}4 / 20 \\
(20)\end{array}$ & $\begin{array}{l}2 / 20 \\
(10)\end{array}$ & $\begin{array}{l}2 / 20 \\
(10)\end{array}$ \\
\hline Blepharitis & $0 / 20$ & $0 / 20$ & $0 / 20$ & $\begin{array}{l}2 / 20 \\
(10)\end{array}$ & $\begin{array}{l}3 / 20 \\
(15)\end{array}$ & $\begin{array}{l}6 / 20 \\
(30)\end{array}$ & $\begin{array}{l}8 / 20 \\
(40)\end{array}$ & $\begin{array}{l}8 / 20 \\
(40)\end{array}$ & $\begin{array}{l}8 / 20 \\
(40)\end{array}$ & $\begin{array}{l}8 / 20 \\
(40)\end{array}$ & $\begin{array}{l}8 / 20 \\
(40)\end{array}$ & $\begin{array}{l}8 / 20 \\
(40)\end{array}$ & $\begin{array}{l}8 / 20 \\
(40)\end{array}$ & $\begin{array}{l}8 / 20 \\
(40)\end{array}$ \\
\hline Stromal keratitis & $0 / 20$ & $0 / 20$ & $0 / 20$ & $0 / 20$ & $0 / 20$ & $0 / 20$ & $0 / 20$ & $\begin{array}{l}2 / 20 \\
(10)\end{array}$ & $\begin{array}{l}2 / 20 \\
(10)\end{array}$ & $\begin{array}{l}8 / 20 \\
(40)\end{array}$ & $\begin{array}{l}8 / 20 \\
(40)\end{array}$ & $\begin{array}{l}8 / 20 \\
(40)\end{array}$ & $\begin{array}{l}8 / 20 \\
(40)\end{array}$ & $\begin{array}{l}8 / 20 \\
(40)\end{array}$ \\
\hline Neovascularization & $0 / 20$ & $0 / 20$ & $0 / 20$ & $0 / 20$ & $0 / 20$ & $0 / 20$ & $0 / 20$ & $\begin{array}{l}2 / 20 \\
(10)\end{array}$ & $\begin{array}{l}2 / 20 \\
(10)\end{array}$ & $\begin{array}{l}8 / 20 \\
(40)\end{array}$ & $\begin{array}{l}8 / 20 \\
(40)\end{array}$ & $\begin{array}{l}8 / 20 \\
(40)\end{array}$ & $\begin{array}{l}8 / 20 \\
(40)\end{array}$ & $\begin{array}{l}8 / 20 \\
(40)\end{array}$ \\
\hline
\end{tabular}

"Mice were inoculated with $10{ }^{6.5} \mathrm{CCID}_{50} / \mathrm{mL}$ infectious particles of HSV-1 in $10 \mu \mathrm{L}$ droplet on each cornea; ${ }^{\mathrm{a}} \mathrm{N}^{\circ}$. of animals showing clinical signs of herpetic ophthalmic infection / of animals clinically examined; ${ }^{\circ} \%$ of animals examined that showed clinical signs of herpetic ophthalmic infection.

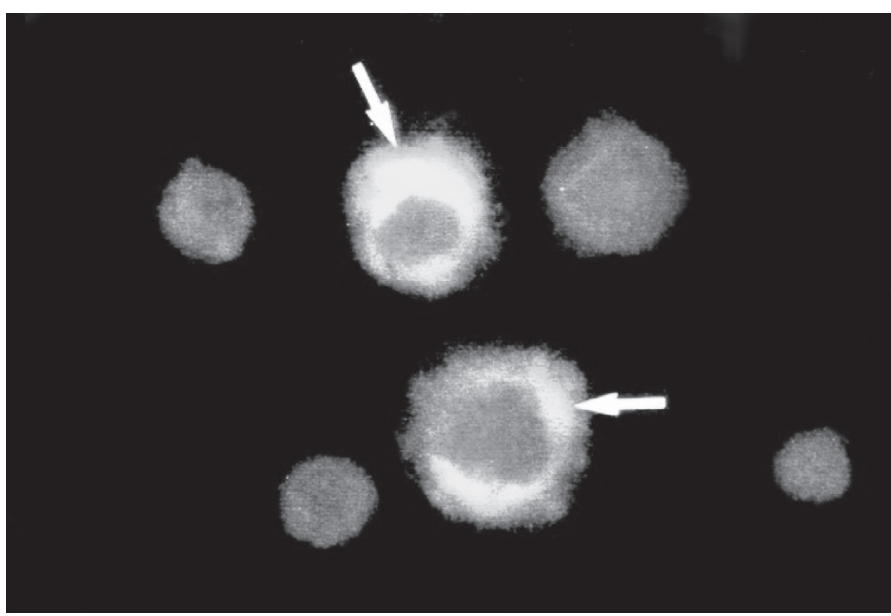

Fig. 1 - HSV-1 specific antigen revealed by indirect immunofluorescence in mouse corneal epithelium. Cells of corneal epithelium obtained by imprint onto glass slide, showing cytoplasmic staining, apple-green fluorescence $(\Longleftrightarrow)$ specific for the viral antigen. $\times 400$.

background of infected cells in red color. As expected, uninfected control mice had negative specimens which exhibited no specific fluorescence. Antigen detection by IIF from corneal imprints of virusinfected mice became visible 18 hours p.i. and declined by $5^{\text {th }}$ day p.i. (Table 2).
Virus isolation from eye swabs: Parallel to IIF, we proceeded to the HSV isolation in Vero cells from conjunctival swabs of mice. As expected, no virus was isolated from conjunctival swabs of uninfected control mice (mock inoculum), while HSV might be isolated from conjunctival swabs of infected mice. In the virus-infected mice we observed that virus shedding appeared 24 hours p.i., peaked three days thereafter, and declined by eight days p.i. (Table 3 ). In HSV-positive Vero cells, CPE was frequently refringency, enlargement and rounding of the cells (Fig. 2).

Cytological and histological findings: HSV ophthalmic infection was also investigated for the presence of typical intranuclear inclusion body, inflammatory response and tissue lesions by the routine H\&E (Fig. 3). Cytopathological and histopathological analysis of infected eyes at various times p.i. frequently showed epithelial lesions as hyperplasy, stromal fibrosis and neovascularization. Multinucleated cells in the corneal epithelium were showed in conjunctival swab slides stained by H\&E. Corneal ulceration related to a predominantly polymorphonuclear (PMN) leukocytic infiltration and edema in the stroma was not infrequently found in H\&E sections. Inflammation of eyelids, conjunctiva, and ciliary body were many times present in infected mouse eyes. In the total of cases of the mice with herpetic ophthalmic infection, few revealed obvious HSV inclusion bodies by the routine $\mathrm{H} \& \mathrm{E}$ sections. In uninfected control mice, the eyes were normal, with no evidence of inflammation, lesions, or cells containing inclusions.

Table 2

HSV-1-specific antigen by IIF from corneal imprints of mice

\begin{tabular}{|c|c|c|c|c|c|c|c|c|c|c|}
\hline \multirow[b]{2}{*}{ Mice } & \multicolumn{10}{|c|}{ Time postinoculation (hours) } \\
\hline & 18 & 24 & 36 & 48 & 60 & 72 & 84 & 96 & 108 & 120 \\
\hline Infected $^{\mathrm{a}}$ & $\begin{array}{c}17 / 20^{\mathrm{c}} \\
(85)^{\mathrm{d}}\end{array}$ & $\begin{array}{l}20 / 20 \\
(100)\end{array}$ & $\begin{array}{c}16 / 20 \\
(80)\end{array}$ & $\begin{array}{c}16 / 20 \\
(80)\end{array}$ & $\begin{array}{c}15 / 20 \\
(75)\end{array}$ & $\begin{array}{c}14 / 20 \\
(70)\end{array}$ & $\begin{array}{c}13 / 20 \\
(65)\end{array}$ & $\begin{array}{c}12 / 20 \\
(60)\end{array}$ & $\begin{array}{l}6 / 20 \\
(30)\end{array}$ & $0 / 20$ \\
\hline Control $^{\mathrm{b}}$ & $0 / 5$ & $0 / 5$ & $0 / 5$ & $0 / 5$ & $0 / 5$ & $0 / 5$ & $0 / 5$ & $0 / 5$ & $0 / 5$ & $0 / 5$ \\
\hline
\end{tabular}

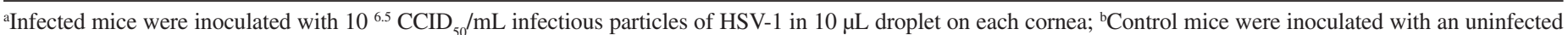
Vero cells suspension (mock inoculum) in $10 \mu \mathrm{L}$ droplet on each cornea; ${ }^{c} \mathrm{~N}^{\circ}$. animals positive / $\mathrm{N}^{\circ}$. animals tested; ${ }^{\mathrm{d}} \%$ of animals positive (HSV-specific antigen). 


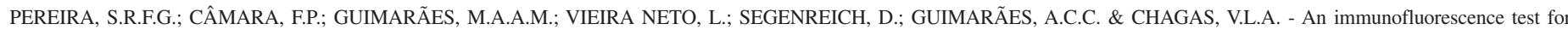
diagnosis of ophthalmic herpes in a mouse corneal model. Rev. Inst. Med. trop. S. Paulo, 49(2): 87-92, 2007.

Table 3

HSV-1 isolation in Vero cell culture from conjunctival swabs of mice

\begin{tabular}{|c|c|c|c|c|c|c|c|c|c|c|}
\hline \multirow[b]{2}{*}{ Mice } & \multicolumn{10}{|c|}{ Time postinoculation (days) } \\
\hline & 1 & 2 & 3 & 4 & 5 & 6 & 7 & 8 & 9 & 10 \\
\hline \multirow[t]{2}{*}{ Infected $^{\mathrm{a}}$} & $9 / 20^{c}$ & $15 / 20$ & $20 / 20$ & $16 / 20$ & $10 / 20$ & $6 / 20$ & $6 / 20$ & $1 / 20$ & $1 / 20$ & $0 / 20$ \\
\hline & $(45)^{\mathrm{d}}$ & $(75)$ & $(100)$ & $(80)$ & $(50)$ & $(30)$ & $(30)$ & $(5)$ & $(5)$ & $(5)$ \\
\hline Control $^{\mathrm{b}}$ & $0 / 5$ & $0 / 5$ & $0 / 5$ & $0 / 5$ & $0 / 5$ & $0 / 5$ & $0 / 5$ & $0 / 5$ & $0 / 5$ & $0 / 5$ \\
\hline
\end{tabular}

Infected mice were inoculated with $10{ }^{6.5} \mathrm{CCID}_{50} / \mathrm{mL}$ infectious particles of $\mathrm{HSV}-1$ in $10 \mu \mathrm{L}$ droplet on each cornea; ${ }^{\mathrm{b}} \mathrm{Control}$ mice were inoculated with an uninfected Vero cells suspension (mock inoculum) in $10 \mu \mathrm{L}$ droplet on each cornea; ${ }^{\mathrm{c}} \mathrm{N}^{\circ}$. animals positive / $\mathrm{N}^{\circ}$. animals tested; ${ }^{\mathrm{d}} \%$ of animals positive (HSV CPE).

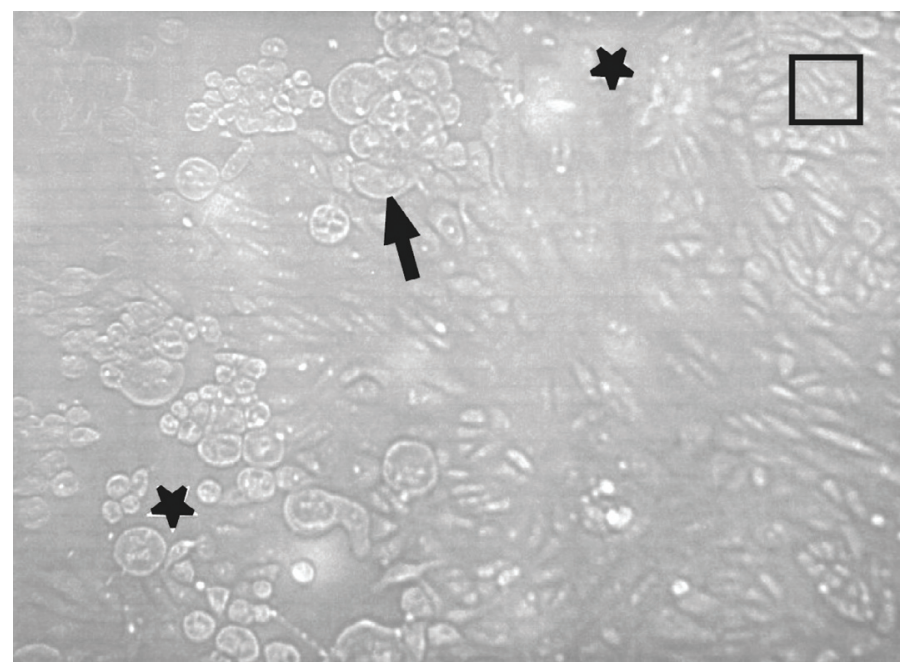

Fig. 2 - HSV-1 isolation in African green monkey kidney cells (Vero) from eye swab of the inferior cul de sac of infected mouse. Cytopathic effect (CPE) in infected cell monolayer, without stain and examined to optic microscope. HSV-1 produced fusion, refringency, enlargement and rounding of the cells $(\longrightarrow$ ), and unfastening of cell monolayer $(\downarrow)$. Note areas where monolayer was still without CPE $(\square) . \times 100$.

\section{DISCUSSION}

The currently accepted method for identifying HSV infection is the isolation of virus in cell cultures. Virus isolation in cell cultures detects small quantities of virus but require a seven days for completion ${ }^{1,2,10,11,16}$. Moreover, the success of HSV isolation using cell cultures depends on the proper specimen collection, transport, and preparation. It also requires considerable technical expertise. Only laboratories experienced in cell culture procedures for virus isolation should attempt to isolate HSV. A negative culture result does not exclude the possibility of a HSV infection. The results should be confirmed by other laboratory method ${ }^{1,2,7,12,13,16}$. Thence, in the virus isolation in cell cultures, after the observation of suggestive HSV CPE we should proceed to an immunological method to confirm the diagnosis.

Analysis of HSV morphogenesis in cell cultures have shown that protein synthesis rapidly occur after infection and some virus-specific proteins are detected earlier by immunological methods $\mathrm{s}^{1,2,7,13,17}$. In contrast to immunological methods, virus isolation in cell cultures has significant disadvantages, including relatively prolonged time to detection, because infective virion is necessary to the development of

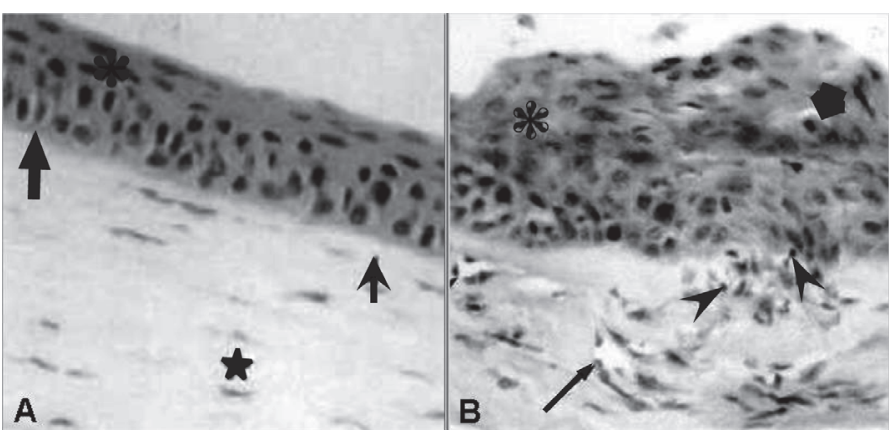

Fig. 3 - Histology of eye starting from uninfected control mouse and HSV-1 infected mouse. A, uninfected control eye: the corneal stratified epithelium $(\boldsymbol{*})$ overlies basal membrane $(\longrightarrow$ ) and Bowman's layer $(\longrightarrow$ ); the collagenous stroma, no blood vessels or lymphatics ( ). B, HSV-1 infected eye: hyperplastic corneal epithelium (*) with degenerative cells $(\downarrow)$; there is vascular neoformation $(\longrightarrow$ ) and leukocytic infiltration $(\longrightarrow)$ in the fibrotic stroma. HE $\times 400$.

total $\mathrm{CPE}^{1,2,16,17}$. HSV immunofluorescence studies have shown that the initial stages of assembly of at least some capsid proteins occur in the cellular cytoplasm ${ }^{2,7,13,17}$. In accordance, our IIF method from corneal imprints showed HSV-1-specific antigen as apple-green fluorescence in the cytoplasm which was detectable 18 hours p.i. and peaked 24 hours p.i. (Table 2). On the other hand, the observation that HSV isolation in Vero cells from conjunctival swabs appeared 24 hours p.i. and peaked three days p.i. (Table 3) also indicated accordance.

The popularity of IIF as a method for identifying viral infections has waxed and waned, but this technique has again become more widely used, in part due to the commercial availability of monoclonal antibodies (mAbs) to a wider variety of viruses than ever before. Most $m A b s$ exhibit excellent sensitivity and specificity ${ }^{7,12,13}$. Advances in $\mathrm{mAb}$ production have resulted in antibodies that are highly specific for HSV. Happily, for the today's virological diagnostic, "licensed kits" are commercially available to provide rapid and accurate detection of HSV infections, and to facilitate the cost-containment by reduction of unnecessary additional detection procedures. In these circumstances, immunofluorescence methods provide the virological diagnostic with cost and time efficient tools. The indirect method has been more sensitive than the direct, because of the amplification possible with the second step, by providing additional fluorescein molecules. Then, we adopted an antigen detection system that uses the fluorescein isothiocyanate-conjugated monoclonal antibody (FITC-mAb) to identify and type HSV in clinical specimens. This system combines 
the specificity and reproducibility of the mAb with the speed and sensibility of an IIF test. Besides, presumptive identification and typing of HSV are possible within few hours in the laboratory. The role of IIF in the virological laboratory diagnostic is further assured by the ability to provide quality control for the system in a coast effective manner. After initial evaluation and titration, minimal quality control to assure consistent reactivity of reagents and regular reviews of technologist's performance are adequate to ensure a sensitive and specific system. Finally, detection of viral antigen on direct clinical specimens has proven useful in rapid diagnosis of viruses. In addition, antigen detection before the appearance of CPE in cell cultures has further enhanced the speed of detection for viral agents. This system has proved useful for HSV and others.

In the present study, the comparison among methods for laboratory detection of HSV ophthalmic infection showed that IIF was more in agreement with the virus isolation than the H\&E routine. In contrast, $\mathrm{H} \& \mathrm{E}$ routine was only a doubtful method to confirm HSV ophthalmic infection, considering that characteristic HSV inclusion bodies were rarely observed in the infected mice. The method of H\&E staining from paraffin-embedded tissue sections is expensive, because it needs specialized equipment and laboratory, and technical expertise. It is also a slow method, because it demands time since the collection and fixation of clinical specimens, embedding in paraffin and sectioning of tissues in rotative microtome, until finally the staining and mounting of glass slides. Moreover, the tissue sections cannot be obtained directly of the alive patient; they can only be obtained of biopsy and autopsy material, and with the retreat of a considerable fragment of the organ to be studied.

In conclusion, our results indicate that this IIF method is quick, specific, and as sensitive as cell HSV isolation. IIF from imprints of virus-infected tissue for antigen detection is a meritorious diagnosis method, because it could not only be applied to biopsy or autopsy specimens but also directly to the patient. IIF from corneal imprints is a practical technique to be employed in animal models for the study of HSV ophthalmic infection. Furthermore, mAbs could be a valuable tool in the diagnosis and identification of HSV ophthalmic infection, with the utilization of IIF from corneal imprints alternative technique of smaller cost and larger speed in obtaining the results than the cell HSV isolation. Hence, we also concluded that the total characterization of mAbs and your employment in IIF from corneal imprints of suspicious patients, before the viral amplification in cell cultures, could be a great proposal for ophthalmic herpes diagnosis.

\section{RESUMO}

\section{Imunofluorescência para diagnóstico de herpes oftálmico usando como modelo córneas de camundongos infectados}

A doença oftálmica do vírus herpes simplex do tipo 1 (HSV-1) é a causa mais comum de cegueira córnea em humanos mundialmente. Técnicas de cultura atuais para HSV levam vários dias e laboratórios de HSV comercialmente disponíveis estabelecem que as técnicas diagnósticas variam em sensibilidade. Nosso estudo foi conduzido para avaliar a aplicação prática de um método mais rápido e simples para diagnosticar o herpes oftálmico. Decalques córneos foram feitos por impressões firmes de olhos de camundongos a lâminas de vidro, depois os decalques foram fixados com acetona fria, e um método de imunofluorescência indireta (IIF) foi executado empregando anticorpos monoclonais no modelo murino de herpes oftálmico. Swabs de córnea foram inoculados em células Vero para o isolamento de vírus a partir de camundongos infectados. A citologia e a histologia do olho foi feita pela rotina de hematoxilina e eosina. Os olhos de camundongos foram examinados através de oftalmomicroscopia para evidência de doença herpética em vários tempos pós-inoculação. A avaliação comparativa da sensibilidade, especificidade e velocidade de métodos para detecção laboratorial de HSV foi feita. Nossos resultados indicam que este método de IIF é rápido, sensível, específico e pode ser útil no diagnóstico de herpes oftálmico como demonstrado no modelo animal.

\section{ACKNOWLEDGEMENTS}

We thank the staff of Pathological Anatomy Service of HUCFF UFRJ for their expert technical assistance. We also thank Dr. C.M. Takya of HUCFF - UFRJ for helpful discussions. This study was supported by grants from CAPES, CNPq, FAPERJ, and FINEP.

\section{REFERENCES}

1. ASHLEY, L.R. \& COREY, L. - Herpes simplex viruses. In: LENNETTE, E.H.; LENNETTE, D.A. \& LENNETTE, E.T., ed. Diagnostic procedures for viral, rickettsial and chlamydial infections. 7. ed. Washington, American Public Health Association, 1995. p. 189-212.

2. ASHLEY, R.L. - Current concepts of laboratory diagnosis of herpes simplex infection In: SACKS, S.L.; STRAUS, S.E.; WHITLEY, R.J. \& GRIFFITHS, P.D., ed. Clinical management of herpes viruses. 4. ed. Washington, IOS Press, 1995. p. 137-171.

3. BARKER, N. - Ocular herpes simplex. Clin. Evid., 11: 871-879, 2004

4. BRANDT, C.R.; COAKLEY, L.M. \& GRAU, D.R. - A murine model of herpes simplex virus-induced ocular disease for antiviral drug testing. J. virol. Meth., 36: 209-222, 1992.

5. FRASER, N.W.; SPIVACK, J.G.; WROBLEWSKA, Z. et al. - A review of the molecular mechanism of HSV-1 latency. Curr. Eye Res., 10: 1-13, 1991.

6. FRITH, P.; GRAY, R.; MACLENNAN, A.H. \& AMBLER, P. - The eye in clinical practice. 2. ed. London, Blackwell Science, 2001.

7. GOLDSTEIN, L.C.; COREY, L.; McDOUGALL, J.K.; TOLENTINO, E. \& NOWINSKI, R.C. - Monoclonal antibodies to herpes simplex viruses: use in antigenic typing and rapid diagnosis. J. infect. Dis., 147: 829-837, 1983.

8. LIESEGANG, T.J. - A community study of ocular herpes simplex. Curr. Eye Res., 10: 111-115, 1991.

9. LIESEGANG, T.J. - Herpes simplex virus epidemiology and ocular importance. Cornea, 20: 1-13, 2001.

10. PEREIRA, S.R.F.G.; GUIMARÃES, M.A.A.M.; VIEIRA NETO, L. et al. - Herpes simplex virus ophthalmic disease induced using two different methods of mice inoculation. Braz. J. infect. Dis., 5: 183-191, 2001.

11. PEREIRA, S.R.F.G. - Otimização de um modelo murino para o estudo da infecção oftálmica induzida pelo vírus herpes simplex do tipo 1. Rio de Janeiro, 2000. (Tese de Doutorado - Instituto de Microbiologia Professor Paulo de Góes da Universidade Federal do Rio de Janeiro).

12. PUPO-ANTUNEZ, M.; HERMIDA-DIAZ, C.; MORIER-DIAZ, L.; GARCIAINFANTE, S. \& RESIK-AGUIRRE, S. - Anticuerpos monoclonales (AcM) que reconocen el virus herpes simple (HSV) y su posible aplicación al diagnóstico. Rev. cuba. Med. trop., 49: 181-185, 1997. 
PEREIRA, S.R.F.G.; CÂMARA, F.P.; GUIMARÃES, M.A.A.M.; VIEIRA NETO, L.; SEGENREICH, D.; GUIMARÃES, A.C.C. \& CHAGAS, V.L.A. - An immunofluorescence test for diagnosis of ophthalmic herpes in a mouse corneal model. Rev. Inst. Med. trop. S. Paulo, 49(2): 87-92, 2007.

13. RIGGS, J.L. - Immunofluorescence staining. In: SCHMIDT, N.J. \& EMMONS, R.W., ed. Diagnostic procedures for viral, rickettsial and chlamydial infections. 6. ed. Washington, American Public Health Association, 1989. p. 123-133.

14. ROMANO, A.; PEISICH, A.; WASSERMAN, D. \& GAMUS, D. - Aggravation of herpetic stromal keratitis after epidermal grown factor topical application. Cornea, 13: 167 172,1994

15. SHIMELD, C.; HILL, T.J.; BLYTH, W.A. \& EASTY, D.L. - Reactivation of latent infection and induction of recurrent herpetic eye disease in mice. J. gen. Virol., 71: 397-404, 1990.
16. SLUMAN, V.J. \& ILSTRUP, D.M. - Predictive value of viral diagnostic tests. In: LENNETTE, E.H.; LENNETTE, D.A. \& LENNETTE, E.T., ed. Diagnostic procedures for viral, rickettsial and chlamydial infections. 7. ed. Washington, American Public Health Association, 1995. p. 155-159.

17. WHITLEY, R.J. - Herpes simplex viruses. In: KNIPE, D.M.; HOWLEY, P.M.; GRIFFIN D.E. et al., ed. Fields Virology. 4. ed. Philadelphia, Lippincott Williams \& Wilkins, 2001. p. 2461-2509.

Received: 15 December 2005

Accepted: 14 September 2006 